DOI 10.18551/rjoas.2019-11.15

\title{
THE PARTICIPATION OF KYAI IN THE ELECTION OF THE HEADMAN IN BULANGAN HAJI VILLAGE, REGENCY OF PAMEKASAN, INDONESIA
}

\author{
Husein Mohammad Bustanol*, Saputri Erina \\ Faculty of Administrative Science, University of Madura, Indonesia \\ *E-mail: inong@unira.ac.id
}

\begin{abstract}
Village Head Election in Pamekasan has entered a new phase. Pilkades simultaneously, which began in 2015 indirectly bring dynamics and shifts in political power. The role of clerics in Madura elite who from the beginning has hegemony tends to shift in the involvement and role of political activity in Madura. Permasalahan clerics raised in this study relates to the chaplain's involvement in village election in the village of Haji Bulangan. The election has taken place followed by candidates who have a personal relationship with a priest in the village of Haji Bulangan. This study uses the concept of the political involvement of Imam Suprayogo (2009: 52). This research was conducted using qualitative methods, with the type of descriptive study based on the basic question of how (Gulo, 2002: 19). This research was conducted to find a model of involvement in the elections to the village clerics in the village of Haji Bulangan. Researchers act as instruments that went to the field to accurate data possible while also using interview techniques, and documentation. Data were analyzed using an interactive model (interactive models of analysis) Miles and Huberman which has three main components are: data reduction, data presentation, and draw a conclusion / verification. This research is expected to contribute to increasing the wealth of research regarding the political elite and its role chaplain.
\end{abstract}

\section{KEY WORDS}

Kyai involvement, village head election, Hajj Bulangan, public service.

Permendagri No. 112 of 2014 concerning Village Head Elections (Pllkades) becomes the legal basis for the simultaneous village head elections. One background was issued by the ministerial regulation to provide certainty in the implementation of the Law on Villages Number 6 of 2014 which will be applied in 2015. The certainty of the implementation of the Act is related to the possibility of vacancy in the position of village head that has the consequence of the conditions to be able to implement the Village Law in 2015 to less complete and become the basis for local governments not to be able to implement the Village Law in 2015.

Kyai in Madura in addition to a role as a religious figure is also the central political figures and highly respected by the community. The figure clerics have a dominant role to influence the social life of people directly and indirectly. In the political vortex, chaplain at Madura post new order enters a new chapter in the political history of clerics. Centralized New Order regime clerics to bring a form of domination that ended up being the only media community's interest in political and social fields. The collapse of the new order gives the main stage Madura's political clerics to participate directly or as political advisors. Madura direct participation of clerics in the form as a candidate in local elections (elections) and legislative candidates (candidates) as evidenced by the election of clerics as regents and legislators. Political advisor or advisor is a form of political participation clerics indirectly.

According to Abdurrozaqi (2010: 153) Village Head Election (klebun) is the political arena that draws the attention of many people in the village. In the selection of the klebun, the political sense that arises among the citizens, especially among the contestants who are competing, this event is not only interpreted as a political event, but also seen as a cultural event. As a political event, the selection of a klebun is an effort of a person or parties involved in it to gain structural political power in the village. By occupying political power in the village, the way to control the bureaucratic functions in the village is wide open.

In 2017, In the village of Haji Bulangan, District Pegantenan, organizing Pilkades followed by the two candidates, namely H. Sukkur (number 1) and M. Zaini (number 2). Vote 
counting results showed a landslide victory of the candidate number 2 , namely M. Zaini. M. Zaini is the incumbent village head (read: klebun) who had a background as an entrepreneur and had been a labor suppliers overseas. From the background shows that he is not the owner breeds clerics and gentility. The second candidate, H. Sukkur is a large family of klebun two previous periods. She is powered directly from the elite of clerics and skipper that most still have family ties. This background in ataskertas should be a strong logistic capital to make him the winner.

Such conditions are one of the political phenomena that occur in one corner of the village in a society that is very thick with a support base chaplain. Chaplain had always been dominant in determining the outcome of an election battle in District Pegantenan shift. Based on the above description is considered necessary to conduct research related to the facts that occurred at the sites.

\section{METHODS OF RESEARCH}

This study included descriptive type based on the basic question of how (Gulo, 2002: 19). Qualitative research is not intended to describe the characteristics of the population or generalize conclusions apply to a population, but rather focused on the representation of the social phenomenon. This research was conducted to find role model clerics in the village election in the village of Haji Bulangan Pamekasan. Based on the formulation of the problem and research objectives, the focus of this study is to identify and describe in the chaplain engagement model village election in the village To Haji Bulangan Pamekasan. The method of analysis used Interactive Data Model of Analysis) Miles and Huberman which has been developed by Johnny Saldana (2013) playing the which has four components, among others; Data collection, data reduction, the data presentation, and drawing Conclusions / verification. In this study the location of the study is Bulangan Haji, Pamekasan, with the data collection M.Zaini (Elected Village Head), Saiful Anam (NU), KH. Abdul Aziz (PP Caregiver. Nurul Jadid), KH. Ahmad Nawawi (Caregiver PP. Miftahul General Buniayu), Nyai Juwayriah (Caregiver PP. Sulton Muhammad).

\section{RESULTS AND DISCUSSION}

The Role of Kyai in the Election of the Headman. Kyai in each election involved even though indirectly involved. The involvement of the Kyai in the election of village heads in Madura as a giver of legitimacy, a provider of spiritual power and can be as an agent of interests. The legitimate role of the cleric is to provide support to one of the candidates with a measure of compatibility with religious teachings that are understood together. The similarity of religious understanding is the main thing in the worship tradition in Madura. Mismatch of understanding can have a negative effect on politicians who want to get the blessing of the clerics. In the case of the competition for village head elections in the village of Bulangan Haji, the religious teaching variables are relatively uniform and homogeneous. Ways and understanding of worship to one another there is no sharp difference. The majority of Islamic boarding schools in the Pegantenan subdistrict have the same direction of the Salafus Salafus manhaj.

Spiritual power is carried out by Kyai by providing support through prayer and munnajah. In Madura's custom, work matters, matchmaking to politics are inseparable from the blessings and advice of the Kyai. Prayer and clerical advice is something that is very expensive and sacred to rural communities. This belief does not only apply to people in rural areas and communities near boarding schools. Urban society still believes in the power of prayer from the Kyai. In the village of Hajj Bulangan, all candidates for the Village Head conduct a prayer ritual together by inviting famous Kyai as lecturers as well as giving prayers and support. The presence of a famous Kyai is enough to give an idea of the direction of support accompanied by the attitude of his pesantren and alumni. This opportunity was used well by each candidate to make the Kyai as a cultural campaign tool. The involvement of the Kyai in the village head election was also driven by personal and group interests. The power and influence of the Kyai will increase significantly when his choice wins the village head election. The interests of groups are also the rationale behind the clerics to be involved in the 
village's political vortex. In this case, the clerics who have a background in groups, educational institutions and mosques have the authority to determine the political direction of their worshipers.

In the village of Bulangan Haji, all candidates received the blessing of the famous Kyai from a large Islamic boarding school in the district of pegantenan. The involvement of clerics is quite dominant in terms of the presence of clerics in every moment of the campaign. The mobilization of the masses by the Kyai was also seen when the incidental events of each campaign took place in the candidacy. In an interview with one of the candidates, the financial capital factor was very important in smoothing his victory. In this case, the village community has been infected with the money political virus. Concerning the capacity of candidates and the support of elite clerics is the second factor after money. The election of village heads in the village of Bulangan Haji, shows that the Kyai is involved, but his involvement does not always result in victory for the candidate he is carrying. The determining factor is the financial capital of the candidate rather than the support of the Kyai.

The Participation of Kyai in the Election of the Headman. According to Imam Suprayogo (2009: 52) argues that elite clerics are at least four clerics nuanced aspects of political activity. First, Kyai by means of education and teaching to convey a nuanced political doctrine. Second, educational institutions organized by clerics likely to be a competitor for educational institutions organized by the government. Third, the students can be directed to a particular political organization. Fourth, the economic aspects can be used by clerics to mobilize the masses.

In a first aspect, the case in the village of Haji Bulangan, ponpes Mainstream give a political signal through scattered small boarding school in Bulangan Haji. In general, the influence of Ponpes Mainstream support will be felt on the ground when a small ponpes give a political signal to the villagers. Kyai caregiver small boarding school since the beginning of the election already has a tendency of choice. In addition to the similarity of the same political background, the other determining factor is the kinship network. In choosing the level of the village head, the small details and actually affect the victory. In the village of Haji Bulangan, only polarized Pilkades competition on the strength of the incumbent with the number two (M. Zaini) and former opponent Defender previous two periods with the number 1 (Sukkur). Based on the interview, M. Zaini said that the campaign strategy diusungnya is the consistency of services provided to all citizens of the village of Haji Bulangan and including areas beyond his (the enemy's). In this case, long before Pilkades, M. Zaini able to infiltrate small ponpes previously sided with him. Intense communication service and is a great way done to conquer the hearts of voters. Though the kinship and networks Mainstream boarding school chaplain, competitors namely Sukkur have the resources to knit both. In this case, Sukkur backgrounds of people able and close to the boarding school. These resources can be maximized with did not seem good. Ttim Sukkur slobbery success in moving machine successful teams in the field. Other than that, simultaneous election actually provides space for the boarding school problems mainsteam to play a political role. Pilkades with time simultaneously make ponpes Mainstram and small ponpes less synergy for successful candidates is carried.

In the Pilgrimage Election of Bulaji Hajj, Kyai cannot use the maximum of education and teaching facilities to convey his political message. This is described in the following explanations. First, the geographical factors of the village of Bulangan Haji, which is not so extensive, causes a limited flow of political messages from large and small PONPES kiai. The clerics' influence finally shifted to the political communication capital used well by candidate number two. M. Zaini who can make a lot of noise because the full-time service tagline for the community can be felt immediately for a long time and continues to be echoed until close to the voting seconds. In this case, the best campaign is what has been done, not what has been said. M. Zaini is proven to be able to use his resources as an incumbent to consolidate his success team with an echoed tagline. The second factor is that the moment of the simultaneous local elections held in the village had a shock effect on the political elite. Pilkades simultaneously made the Kyai elite unable to consolidate the power of identity politics by channeling it in the educational institutions they owned. In the second aspect, body boarding school owned by clerics in the village of Haji Bulangan dominantly controlled distribution map of educational institutions in the village as well as in the District Pegantenan. 
Pesantren strong culture does not give the slightest opportunity for public education institutions to participate in the political struggle. Some formal educational institutions owned by the state eventually will follow the flow of the existing political culture. In this case, it appears that no distinctiveness Madura other regions. Therefore, researchers do not go into the second aspect is not relevant due to the real conditions in the village of Haji Bulangan.

The third aspect, the participation of students in formal political activities. Mainstream boarding school in the area Bulangan Haji affiliated to a political party PKB, PONPESP and the United Nations. This political line inherited from the parent organization of the NU community, Syarikat Islam, and Masjumi (read: political parties dissolved the old order). In terms of the characteristics of religious rituals basically have in common, whereas in the political line, of course, more fluid and dynamic. In the 2014 legislative elections, if ordered by the political party affiliated above, CBA was ranked first, followed PONPESP and the UN in the second and third positions. In Sub Pegantenan and District Palengaan, legislative candidate wins more because of the support of the boarding school as the main background of the candidate. Support from boarding school led to an intense relationship that tug of war between parties and large family cottage, one of which is the alumni.

In the case of Haji Bulangan, the participation of small boarding school students (a large family boarding school) located in the village was very little. Political participation of students is usually in the form of informal support because Ponpes background factors and kinship. Based on interviews, the students hardly ever mobilized to become a member of a particular party. Often, however, the students were asked indirectly to support a particular party affiliation. In 2017 Pilkades moment, the alumni santrilah main targeted to achieve sound support. This support is psychological have a similar background as students. In this case, M. Zaini an alumnus ponpes could lead Banyuanyar opinions 'kesantriannya' to many people for making a lot of noise. M. Zaini with the limitations of his family background, able to juggle brand image "figure of students" on him. This strategy proved successful attached himself to many Ponpes. Instead, what happened to Sukkur, family background has a high social stratification and have the image of students, it does not add significant noise. The main reason is the absence of a mature concept of the campaign so that he failed to overtake electability M. Zaini. In this third aspect, the students are not mobilized in formal political activity but directed indirectly by supporting one of the candidates based on the proximity of the boarding school alumni. Happened to Sukkur, family background has a high social stratification and has the image of students; it does not add significant noise. The main reason is the absence of a mature concept of the campaign so that he failed to overtake electability M. Zaini. In this third aspect, the students are not mobilized in formal political activity but directed indirectly by supporting one of the candidates based on the proximity of the boarding school alumni. Happened to Sukkur, family background has a high social stratification and has the image of students; it does not add significant noise.

The fourth aspect, Haji Bulangan In the case, according to interviews with leaders Ponpes Bulangan Haji Nurul Jadid, suggests that economic activity in rural communities have no effect on political choice. In this case the elite of clerics in the village do not have enough resources that can play such opportunities. Kyai in the village more focus on education and teaching institutions. Economic activity is still used as umpteen numbers because they cannot be managed properly by a small boarding school in Bulangan Haji.

According to the results of interviews with residents, customs Ponpes in Bulangan Haji just focus on improving its schools. This understanding has not shifted due to insufficient purchasing power in the rural environment. In addition the business capital and understanding of business management at the village level is still not obtained by Kyai manager Ponpes. In this case, clerics in the village have not been able to play its role in economic activity. The role of the usual clerics in general is moving among bosses or employers Madura tobacco in the form of feedback and suggestions. In this position clerics regarded as the sacred and used as a back up to the skipper to secure business activity. The relation between the skipper and these clerics remain ultimately culminate in benefit of mutual relations and lead to political synergies. At the moment Bulangan Haji village elections, relations skipper and clerics utilized by candidate M. Zaini. These resources are well maintained for a long time. M. Zaini care for good relations when previously he worked as an entrepreneur. 


\section{CONCLUSION}

Based on the results of research and discussion with the title involvement clerics in Village Head Election Bulangan Haji Pamekasan in accordance with the typology proposed by Imam Suprayopgo (2009: 52) concluded that The election of village heads in the village of Bulangan Haji, shows that the Kyai is involved, but his involvement does not always result in victory for the candidate he is carrying. The determining factor is the financial capital of the candidate rather than the support of the Kyai. The clerics are dominantly involved in political activities in aspects of educational facilities and economic interests for mass mobilization.

In a first aspect, at Pilkades in the village of Haji Bulangan, the Mainstream ponpes give a political signal through scattered small boarding school in Bulangan Haji. In general, the influence of Ponpes Mainstream support will be felt on the ground when a small ponpes give a political signal to the villagers. Kyai caregiver small boarding school since the beginning of the election already has a tendency of choice. Nonetheless At Bulangan Pilkades Haji, Kyai cannot be used with a maximum supply of education and teaching to convey political messages.

In the second aspect, body boarding school owned by clerics in the village of Haji Bulangan dominantly controlled distribution map of educational institutions in the village as well as in the District Pegantenan. Pesantren strong culture does not give the slightest opportunity for public education institutions to participate in the political struggle. Some formal educational institutions owned by the state eventually will follow the flow of the existing political culture.

In a third aspect, the participation of small boarding school students (a large family boarding school) located in the village was very little. Political participation of students is usually in the form of informal support because Ponpes background factors and kinship.

The fourth aspect of economic activity in rural communities has no effect on political choice. In this case the elite of clerics in the village do not have enough resources that can play such opportunities. Kyai in the village more focus on education and teaching institutions. Economic activity is still used as umpteen numbers because they cannot be managed properly by a small boarding school in Bulangan Haji. The role of the usual clerics in general is moving among bosses or employers Madura tobacco in the form of feedback and suggestions. In this position clerics regarded as the sacred and used as a back up to the skipper to secure such activity.

\section{REFERENCES}

1. Budiardjo, Miriam. Dasar-dasar Ilmu Politik. Jakarta: Gramedia, 1998.

2. Haris, Syamsuddin. 2003. Desentralisasi and Otonomi Daerah. Jakarta: LIPI Pers.

3. Keller, Suzanne. Penguasa and Kelompok Elit. Jakarta: Rajawali. 1984.

4. Kuncoro, Mudrajad, 2004. Otonomi and Pembangunan Daerah, Reformasi, Perencanaan, Strategi and Peluang. Jakarta: Erlangga.

5. Kartono, Kartini. (1998). Pemimpin and Kepemimpinan: Apakah Pemimpinan Abnormal Itu? PT Raja Grafindo Persada, Jakarta.

6. Kasdi, Aminuddin. 2007. Perlawanan Penguasa Madura Atas Hegemoni Jawa. Yogyakarta: Jendela Grafika.

7. Rozaqi, Abdur, 2004, Menabur Kharisma Menuai Kuasa, Yogyakarta: Pustaka Marwa.

8. Sartono Kartodirjo, 1990, Kepemimpinan dalam Dimensi Sosial, Jakarta LP3ES Sokamto, 1999. Kepeimimpinan Kyai dalamPesantren.Jakarta: LP3ES. Suprayogo, Imam, 2007, Kyai and Politik. Malang: UINMalang Press.

9. Suzanne Keller, 1995, Penguasa and Kelompok Elite. Jakarta: PT Raja Grafisindo Persada.

10. Jurnal Aspirasi, Vol 3, No.1 Januari 2018:28-34.

11. Jurnal Sosiologi Masyarakat, Vol.17, No.1, Januari 2012: 23-48 Jurnal Karsa, Vol. XI, No1, April 2007.

12. Jurnal Karsa, Vol. XIII, No.2, Oktober 2017. 